\title{
THE CONTRIBUTION OF THE PUBLIC AUTHORITIES FROM THE REPUBLIC OF MOLDOVA TOWARDS THE PROTECTION AND ENHANCEMENT OF THE NATIONAL CULTURAL HERITAGE
}

\author{
Vasile Comendant* \\ Academy of Public Administration, Republic of Moldova, E-mail: comendv@gmail.com
}

(Received: December 2020; Accepted: March 2021; Published: May 2021)

\begin{abstract}
The article analyzes the contribution of the public administration authorities of the Republic of Moldova towards the protection and enhancement of the national cultural heritage. The competencies of the Parliament, the Executive and Ministry of Education, Culture and Research are investigated as central public authorities in the field of national heritage, as well as the attributions of local public authorities in this field. The attention is on the relationship of cooperation between the central public authorities and the local ones in certain areas. It is underlined the contribution of the European Union's projects towards the reconstruction of some historical value objectives as part of the national heritage. Particular attention is given to the role of cultural heritage in the education of citizens by systematizing the knowledge about national and global cultural heritage.
\end{abstract}

Keywords: the Republic of Moldova; central public administration authorities; local public administration authorities; cultural heritage; legal framework; historical monuments; international conventions; heritage education.

\section{Introduction:}

In the last decades, mankind has faced problems, the solution of which depends on the human civilization's existence itself. These problems became global, which labeling is coming from Latin globus. The evolution of humanity has influenced the cultural life too, in which, with regret, today is attested, a widespread of concepts, doctrines and directions with anti-cultural character. However, their existence cannot be considered a foundation of cultural degradation in general, a perspective lack in the direction of cultural self-improvement of mankind. Now it has appeared the new field of activity, it has increased their diversity; this fact is determined by the scientific and technical development. Also, the new inventions and activities are proof that the humanistic values of mankind are not forgotten. On the contrary,

*Corresponding author: Vasile Comendant. E-mail: comendv@gmail.com

Copyright (C) 2021 The Author(s). Published by VGWU Press

This is an Open Access article distributed under the terms of the Creative Commons BY 4.0 license (Creative Commons - Attribution 4.0 International - CC BY 4.0) which permits unrestricted use, distribution, and reproduction in any medium, provided the original author and source are credited.

72 Sciendo Journal of Legal Studies Volume 27 Issue 41/2021 ISSN 2457-9017; Online ISSN 2392-7054 
The Contribution of the Public Authorities From the Republic of Moldova Towards the Protection and Enhancement of the National Cultural Heritage

lately, it persists the idea that these values will contribute to the development of global problems.

We conclude that cultural heritage is the quintessence of mankind's existence. Every man throughout his life manages to assimilate, to root in his inner world only a small part of the cultural heritage, which defines him as an intelligent person. This phenomenon can occur only in the context of heritage preservation and heritage education.

\section{National Cultural Heritage}

National cultural heritage represents the state of mind of the nation, accumulated over the centuries and includes "the totality of cultural values and assets" [1]. Or "the totality of movable and immovable cultural assets of special value - determined as such - and representative for the history of the nation, which has the virtue to designate this, it forms the national cultural heritage" [2, pp. 22].

Also, the social progress of mankind depends on the problem regarding the protection and valorization of the cultural heritage. It is a problem characterized by dynamism, appeared as an objective factor in the development of society, and for its solving, it is required the active involvement of public authorities, as a bearer of the perspective of preserving humanistic values and society developing.

On November 231972 at the General Conference of the United Nations Organization for Education, Science and Culture, gathered in Paris, was adopted the Convention on the protection of world cultural and natural heritage [3], in which it was emphasized that the natural cultural heritage it is increasingly threatened of destruction, not just from common causes of degradation, but also through the evolution of social and economic life which aggravates them by phenomena of alteration and destruction. In this Convention is outlined the educational component, signatory states requesting the creation of education programs for citizens towards the cultural and natural heritage, especially, being identified dangers that threaten this heritage.

The Republic of Moldova has acceded to this convention in June 2002 but is not in total agreement with Article 16 concerning financial contributions to the World Heritage Fund.

In Western European countries, the educative work with citizens concerning the protection and preserving the cultural and natural heritage is a common fact for a long time of state institutes and authorities. As a result of signing the Framework Convention of the Council of Europe concerning the value of cultural heritage for society, on October 272005 the education work has intensified. [4]

The document particularly underlines the link between cultural heritage, as a source of memory, understanding, originality, and the unity of nations. For example, many 
Comendant, V., (2021)

The Contribution of the Public Authorities From the Republic of Moldova Towards the Protection and Enhancement of the National Cultural Heritage

European countries, such as Austria, France, Romania, Poland achieves the project "Aquaduct" of the Lifelong Learning Program, which has the purpose - "assimilation of the key competences through heritage education" [5].

In 2007 during The European Cultural Forum, which took place in Milano, it has been officially launched -2018 the European Year of Cultural Heritage. It reiterated that 2018 will be an unprecedented year for the number and importance of panEuropean activities and initiatives which refers to the public and professionals from the field of Cultural Heritage. The goal of the European Year of Cultural Heritage is an encouragement of the society, authorities to discover and explore the European Heritage, to increase the acknowledgment for history and common values, and to strengthen the belonging to the cultural diversity from the European space.

In this context, we specify that the enhancement of the cultural heritage represents a distinct signification, a proof of its historical evolution, which contributes to establishing the universal cultural values. So, cultural heritage represents the expression of values of a person, as well as of a community or region, which represents a public, general, national interest. This general public interest manifests itself through protection and valorization of cultural heritage and represents the source of the legitimacy normative action of public authorities, central or local, on the entire national territory. The cultural vestiges inherited from our ancestors certify the patrimonial value of these. The cultural heritage represents "...the most important link between the past and the present of every society" [6, pp. 38-44]. "The attitude that we have today toward this heritage can assure us either a prosperous or an uncertain future" $[7, \mathrm{pp} .5]$. The preservation of cultural heritage has to constitute a mandatory rule for all citizens of the community, which members they are. The Republic of Moldova is not an exception, with this purpose the protection arrangements have been stipulated in normative acts and are a task for the citizens and public authorities.

\section{Legal enactments}

The research of this problem denotes that after the independence proclamation, the authorities of the Republic of Moldova, have elaborated more normative acts, which target cultural heritage protection. The legal framework of national cultural heritage is grounded in the Constitution of the Republic of Moldova. The legal aspects of the cultural heritage of the Republic of Moldova are endorsed in many laws as The Law regarding the protection of monuments, The Law regarding the protection of archaeological heritage, The Law regarding the protection of national cultural mobile heritage, The Law regarding the protection of the immaterial cultural heritage. Through these Laws, the state authorities had the intention to nurture the respect of the citizens and recognition of heritage values at a local and national level.

74 sciendo Journal of Legal Studies Volume 27 Issue 41/2021 ISSN 2457-9017; Online ISSN 2392-7054. 
The Contribution of the Public Authorities From the Republic of Moldova Towards the Protection and Enhancement of the National Cultural Heritage

Some particular aspects concerning cultural heritage, are mentioned in other laws, as The Law of Culture, The Law of Museums, The Law regarding Archive Fund of the Republic of Moldova, The Law regarding architectural activity, the Government Decision regarding the approval of the strategy of development of culture "Culture $2020 "$, and of action plan regarding its implementation.

As well as the laws elaborated specially for the protection of national cultural heritage, this field interfaces with the national Codes: Civil Code, Criminal Code, Customs Code, The Code regarding the administrative contraventions, Fiscal Code, and other regulations based on the above-mentioned documents.

For supporting the actions concerning the protection of the heritage, the Republic of Moldova ratified a number of conventions. The most important are: European Convention regarding the protection of archaeological heritage, UNESCO Convention regarding the protection of the cultural, natural global heritage, UNESCO Convention regarding the safeguard of immaterial cultural heritage, UNESCO Convention regarding the protection and promotion of cultural expression diversity, the European Framework Convention regarding the value of cultural heritage for society. In this regard, the state authorities have tried to harmonize the national legislation with the international Conventions and to implement it according to the competencies of executive authorities. Even the legislation confirms the supremacy of international treaties, to which the Republic of Moldova is a part of, this clause, usually, is not applied, because the ratification of international acts is followed by the state obligation, to adjust the national legislation - purpose difficult to achieve. So, we conclude that from 11 Conventions in the field of cultural heritage, signed by the Republic of Moldova only the Convention from Valletta can be found in the Law regarding the protection of archaeological heritage. The other Conventions, as normative national acts are still at the stage of intentions and projects.

Even the legal national frame seems to be sufficiently wide and complex, it doesn't stimulate enough the proper administration of the heritage - at its potential, but in some situations, it produces stopping effects of the enhancement process. This denotes that the current legislation is not sufficiently developed. To all this, we can add the malfunction of the public administration activity.

The safeguard and enhancement of the national cultural heritage of the Republic of Moldova are established by the Government and the Parliament, according to the Laws of the Republic of Moldova. The powers concerning the maintenance, the use, and location of the objects and objectives having a special value of national cultural heritage, are established at the initiative of the Government, by the Parliament, according to the notices of commissions of independent experts, taking into account 
the interest of the integrity of collections historically constituted, its storage conditions, and the access possibilities to them [8].

The Government develops concrete and efficient policies in the field of cultural heritage safeguard and establishes and updates the National Register of Monuments. The Executive elaborates the state Program regarding the protection, preservation, and restoration of the monuments, as well as the financing of this program from the state budget.

According to the Law regarding the protection of monuments, the Parliament of the Republic of Moldova develops state policy concerning the safeguard, protection preservation of the monuments, that forms cultural and natural heritage, approves the National Register of Monuments, state Programs, and funds. It approves the state Program regarding protection, preservation, and restoration of the monuments, financing of this program, granting of non-reimbursable subsidies from the state budget [9].

\section{The contributions of Republic of Moldova Public Authorities towards national cultural heritage}

The Ministry of Education, Culture, and Research is the central specialized public authority, responsible for the implementation of policies, strategies, and specific regulations, for the safeguard of the national cultural heritage. According to the current legislation, the mentioned public authority develops different programs regarding the identification, documentation, researching, protection, preservation, restoration and evaluation of heritage objects. [10] Also, it approves and elaborates different regulations in the field of national cultural heritage, files, and certificates of recognition of achievements, gives notices for the documentation that concerns the construction and the location of the monuments, elaborates rules and specific methodologies, the compliance with legal provisions in this field.

The Ministry of Education, Culture, and Research supervises the method of implementation of the legislation regarding the protection, preservation, and restoration of archeological heritage. The Ministry initiates different proposals of improvement of the national legal framework, in order to be adjusted to the international treaties in the field of protection of cultural heritage, performs international cooperation, common projects and programs with other states or international bodies, concerning the safeguard activities of the state cultural heritage, assures the fulfillment of the commitments taken through international Conventions, regarding the protection of archeological heritage, to which the Republic of Moldova is a part of [11]. 
The National Archeological Agency represents the specialized public institution that contributes to the implementation of policies in the field of protection and valorization of heritage and archeological remains.

In the light of the above, we conclude that the state guarantees the propriety and assures, in accordance with the current normative frame, the protection of the assets which are part of the cultural heritage of the Republic of Moldova.

The administration of local and central public authorities cooperates in certain fields. They are responsible, according to the current legal framework, for the safeguarding activity of the national cultural heritage. The authorities of local public administration are the legal exponents of the communities that own heritage. They are responsible for the cultural heritage objects that are located on their territory.

In the public local administration of the second level, practically work, "... in every district and municipality, division for culture, architecture and environment, which elaborates policies in this field" [12, pp. 21]. The district councils, the municipal Division for culture from Chisinau, and the municipal Division for culture from Baltsi supervises the activity of the cultural local institutions. The main objectives of these Divisions are the assurance of the required conditions for the development of the artisanal art, of cultural and recreational activities, to achieve preservation and promoting programs of culture and art in districts municipalities through the organization of different cultural events that promote the preservation and advertising of popular art, amateur groups, artisanal art exhibitions and to present to the Ministry of Education, Culture and Research, to district/municipal council the annual report regarding their activities and the subordinated institutes [12].

According to the current national legislation the district, municipal, city councils contributes to the elaboration of programs regarding identification, documentation, protection, preservation, submission, promotion, revitalization and valorization of the cultural heritage of local importance. The public local administration draws up the Register of Monuments of local importance. In order to achieve the mentioned programs, the local public administration authorities need to foresee in annual budgets needs for the financing or co-financing the activities of safeguard of the elements of cultural heritage, non-reimbursable subsidies for local budgets. We conclude that in many administrative-territorial units, because of the restricted budgets and the economic potential limited in development, this clause is not achieved partially. That is why local authorities benefit in this purpose of transactions with special destination from the state budget, according to the law.

During the last years, the local public administration authorities are more involved in the development of tourism. Due to support from central public administration authorities, and the obtained grants from the projects of the European Union, local authorities managed to rebuild some objective of historical value, a part of national 
Comendant, V., (2021)

The Contribution of the Public Authorities From the Republic of Moldova Towards the Protection and Enhancement of the National Cultural Heritage

heritage. Among them: Hotin, Soroca, Suceava Fortresses - in the frame of transborder project "Medieval jewelry", achieved by the common operational program Romania - Ukraine - Republic of Moldova 2007-2013, financed by European Union. The partners of the project are the City Hall of Soroca (Republic of Moldova) Suceava municipality (Romania) state reservation of history and architecture - Hotin Fortress (Ukraine). The total value of the project is 3 million euros, 2 million euros were allocated for the reconstruction of Soroca Fortress.

A contribution from local authorities is achieved through the National Fund of Regional Development of the Republic of Moldova and with the support of the European Union through the project "Development of the trans-border tourism through the promotion of the Mansion of ManucBey, Elena IoanCuza Mortuary and the Blesciunov Museum. The program is part of the Joint Operational Programme Romania-Ukraine-Republic of Moldova, financed by the European Union through the European Neighborhood and Partnership Instrument. It is implemented by the district council Hancesti in common with two external partners: City Hal of Solesti from Vaslui (Romania) and Municipal institution the museum of personal collections A.V. Blesciunov from Odesa (Ukraine). The total value of the project is almost 2,5 million euros, $90 \%$ of which are non-reimbursable financing from the European Union. As a successful implementation of the Project of renovation of the historicalarchitectural Complex Mansion Manuc-Bey, in 2016, the company which installed illumination of touristic attraction, won one of those 12 prestigious prizes at Excellence Awards 2016 at the Exhibition "Prolight + Sound" which annually takes place in Frankfurt (Germany), the award from the field of architectural illumination. At this contest participated distributors from 64 countries.

At the moment in the Republic of Moldova are being implemented and other projects of reconstruction of touristic cultural attractions (COMUS Project, through the CHOICE program it has been launched the project "Rebirth of the history - the inclusion of the Old Duruitoarea cave in the European touristic itinerary", which will contribute at the development of regional and rural tourism. The efforts of public authorities must be directed further to the tourism development in cities and villages from the Republic of Moldova and best efforts for the emancipation of provided services, through training of staff and managers in the condition of amplification of the programs of superior valorization of cultural heritage and natural landscape from each location.

The sustainable development of tourism in the Republic of Moldova is indispensable related to the improvement by the administration of local authorities, of the settlement infrastructure, especially rural, as well as public services. The infrastructure and improper basic services represent the main element which maintain the gap between rural and urban zones in our country and which represents 
The Contribution of the Public Authorities From the Republic of Moldova Towards the Protection and Enhancement of the National Cultural Heritage

an obstacle in the way of equality of chances and development of socio-economical rural zones.

In the field of immaterial cultural heritage, administration of public local authorities assures the viability of the traditional creation of the communities in its authentic and unchangeable forms, takes recognition measures from de communities of which part they are, of the citizens that preserve and transmit elements of immaterial cultural heritage to the wide audience. At the same time, the authorities assure the protection of viable forms of traditional expressions, support the heritage bearers on the administered territory, contributes to the revitalization of the lost elements, which are important for the community identity, develops community initiatives, regarding the protection and the revival of the traditional way of life, especially of immaterial cultural heritage elements, that can be a source of economical and social development at the local level. [13]

Taking account of the social, cultural and political-economical importance it is necessary that the public administration authorities bring contribution to the knowledge and promotion of national cultural heritage towards native citizens and towards foreigners (tourists in the Republic of Moldova, immigrants, members of Diplomatic Corp, different international, European bodies) To efficiently achieve this, there necessary the following actions: studying and understanding of the owned cultural heritage, continuous development of the heritage through the incorporation of new values having special cultural importance, proper preservation and protection of components, heritage management, public management and those who are interested, creation of an adequate valorization system, cooperation and communication with different cultural communities, as well as with economical agents or public on non-profit private organizations, interested in cultural development.

In order to protect archaeological heritage, local public administration authorities have competencies in cooperation with public bodies and institutions with responsibilities in the field for implementation and enforcing their decisions. Local administration assures protection of archaeological heritage, as a result of systematic or preventive archaeological research and archaeological fortuitous discovery located on the public property of administrative-territorial units. As well, this includes in its social-economical and urban development programs, spatial planning, and specific objectives regarding the protection of archaeological heritage. [14] The protection of archaeological heritage is not just included in the competencies of state public authorities or archaeologists; It is a part of common cultural heritage, and its protection is a moral duty for the nation in order of its preservation for future generations. 
Comendant, V., (2021)

The Contribution of the Public Authorities From the Republic of Moldova Towards the Protection and Enhancement of the National Cultural Heritage

In 2012 for the first time from the Declaration of Independence, The Ministry of Culture with the support of the United Nations Development Program has initiated the process of elaboration of the National Strategy for Culture Development "Culture 2020". The document was finalized and approved with the Government decision $\mathrm{Nr}$ 271 from 09th of April 2014. It was elaborated the action plan regarding its implementation.

The purpose of the strategy: promotion of the development guidelines and supervision of the cultural process from the Republic of Moldova which should contribute to the social-cultural development of the country, through assurance of an efficient institutional and legal framework for the cultural environment; Creation of a functional preservation system and valorization of cultural heritage; Promotion of creativity and the cultural-political development; Efficiency of cultural management, for the improvement the quality of life of citizens, of social cohesion.

\section{Conclusions}

We conclude that one of the main problems that public administration confronts in the field of protection and valorization of national cultural heritage is the lack of allocated funds for this field and the legal imperfections that do not allow the local public administration to involve independently in the process of revitalization and protection of cultural heritage. Remedy of difficulties can be solved by creating an adequate and modern legal framework, which will offer wide possibilities in organizing infrastructure and viable programs of management of national cultural heritage.

The valorization of cultural heritage by public administration authorities must have a global approach, with a special influence on the development policies of the territory of the Republic of Moldova. There are necessary legal regulations and organizational regulators, changing the individual and collective attitude towards the cultural heritage, promotion of interest for the safeguard and its preservation.

Cultural heritage has a special role in the education of citizens. The use of cultural heritage in education is not limited only to the historical or art component, it includes a variety of resources beside them that suppose an enormous potential for creating and supporting the motivation, innovative attitudes, especially public administration authorities. "Cultural heritage as a part of culture is a socio-cultural phenomenon, because the member of a society creates the culture, but the culture forms the citizen" [15, pp. 211].

To become a community unification factor, the cultural heritage, where the individual can appreciate its past, the beauty of the environment, it is necessary to establish a heritage education by knowledge systematization about the national

80 S sciendo $\begin{aligned} & \text { Journal of Legal Studies Volume } 27 \text { Issue 41/2021 } \\ & \text { ISSN 2457-9017; Online ISSN 2392-7054. }\end{aligned}$

ISSN 2457-9017; Online ISSN 2392-7054.
Web: publicatii.uvvg.ro/index.php/jls. Pages $72-82$ 
The Contribution of the Public Authorities From the Republic of Moldova Towards the Protection and Enhancement of the National Cultural Heritage

global cultural heritage, especially by using modern information technology and the development of cultural tourism.

However, we consider that specialized central public administration authorities should include in educational programs, various training and promotion of culture and national heritage, guided by the principle of professor, museographer Alexander Tzigara-Samurcas, according to whom "to teach, and above all, to educate means to include the child into the nation he belongs to" $[16, p .8]$. The educational process can take place by adopting a national program concerning the knowledge of the values of traditional cultural heritage, using this purpose the museum of Ethnography collections and artisanal art and open-air pavilions, as primary sources of experimental knowledge.

It is necessary for the Ministry of Education Culture and Research of the Republic of Moldova to elaborate new cultural policies and to create new specialized institutions in this field: Heritage Agency, The Institute of National Heritage which will implement these policies.

The competencies of public administration have to refer to the involvement at a local and central level, in many knowledge projects and promotion of national cultural heritage. It is also indispensable to achieve the cooperation and communication of these authorities with different cultural communities, as well as with economical agents or public or private non-profit organizations that are widely interested in cultural development.

\section{Acknowledgments}

The author thanks the anonymous reviewers and editor for their valuable contribution.

\section{Funding}

This research received no specific grant from any funding agency in the public, commercial, or not - for - profit sectors.

\section{Author Contributions}

The entire article was written by Vasile Comendant.

\section{Disclosure Statement}

The authors have not any competing financial, professional, or personal interests from other parties.

\section{References}

[1] Legea culturii, nr. 413 din 27.05.1999. In: Monitorul Oficial al Republicii Moldova, 1999, nr. 83-86/401, art.2.

[2] Opriș, I. (2000). Transmuzeographia. București: Oscar Prinț. 
Comendant, V., (2021)

The Contribution of the Public Authorities From the Republic of Moldova Towards the Protection and Enhancement of the National Cultural Heritage

[3] Convenția privind protejarea patrimoniului mondial, cultural, și natural. https://whc.unesco.org/en/basictexts/, accessedat [20.03.2020].

[4] Convenția - Cadru a Consiliului Europei privind valoarea patrimoniului cultural pentru societate. //https://rm.coe.int/1680083746, accessedat [24.03.2020].

[5] https://docplayer.nl/75779587-Insusirea-competentelor-cheie-prin-educatiapatrimoniala.html accessed [28.02.2020].

[6] Cavruc, V., Postică, Gh. (2010). Salvgardarea patrimoniului cultural național al Republicii Moldova. In: Akademos nr. 2(17), pp. 38-43. Chișinău: Academia de Științe a Moldovei.

[7] Ursu, V. (2013). Noi tendințe în promovarea patrimoniului cultural național și european. Chișinău: Pontos.

[8] Legea culturii, nr 413-XIV din 27.05.1999. In: Monitorul Oficial al Republicii Moldova, 1999, nr. 83-86/401, art. 17.

[9] Legea privind ocrotirea monumentelor, nr. 1530-XII din 22.06.1993. In: Monitorul Oficial al Republicii Moldova, 2010, nr. 15-17/23, art.11.

[10] Legea privind ocrotirea monumentelor, nr. 1530-XII din 22.06.1993. In: Monitorul Oficial al Republicii Moldova, 2010, nr. 15-17/23, art.55.

[11] Legea privind protejarea patrimoniului cultural imaterial, nr. 58 din 29.03.2012. In: Monitorul Oficial al Republicii Moldova, 2012, nr.76-80/255, art. 13.

[12] Legea privind protejarea patrimoniului arheologic, nr. 218 din 17.09.2010. In: Monitorul Oficial al Republicii Moldova, 2010, nr.235-240/738, art.12.

[13] Musteaţa, S. (2011). Patrimoniul Cultural al Republicii Moldova - Probleme de legislaţie şi management. In: Patrimoniul cultural al Republicii Moldova: de la realitate la necesitate. Chişinău: „Continental Grup SRL”.

[14] Legea privind protejarea patrimoniului cultural imaterial, nr. 58 din 29.03.2012. In: Monitorul Oficial al Republicii Moldova, 2012, nr.76-80/255, art. 18.

[15] Legea privind protejarea patrimoniului arheologic nr. 218 din 17.09.2010. In: Monitorul Oficial al Republicii Moldova, 2010, nr.235-240/738, art.18.

[16] Comendant, V. (2018). Public policies implementation in the field of national cultural heritage. In: Revista de Filozofie, Sociologie și Științe Politice, nr. 1 (176), pp. 208-220. Chișinău: Academia de Științe a Moldovei.

[17] Tzigara-Samurcaș, Al. (2012). Dezvoltarea durabilă a satului românesc. Patrimoniul cultural tradițional și natural - abordare interdisciplinară. USR: Departamentul de Publicații.

82 sciendo Journal of Legal Studies Volume 27 Issue 41/2021 ISSN 2457-9017; Online ISSN 2392-7054.

Web: publicatii.uvvg.ro/index.php/jls. Pages $72-82$ 